\title{
Evidence for a developmentally regulated prespore-specific glutamine synthetase in the cellular slime mould Dictyostelium discoideum
}

\author{
Andrew J. Dunbar and John F. Wheldrake \\ Author for correspondence: Andrew J. Dunbar. Tel: +61 8201 2032. Fax: +61 82013015.
}

School of Biological Sciences, The Flinders University of South

Australia, Bedford Park, GPO Box 2100,

Adelaide 5001, Australia

\begin{abstract}
The enzyme glutamine synthetase (GS) is described for the first time in Dictyostelium discoideum. The appearance of this enzyme is developmentally regulated. The level of activity is low in vegetative cells and increases more than threefold during differentiation. Furthermore this enzyme is shown to be differentially localized in prespore cells, the specific activity being approximately fourfold higher than in prestalk cells. The enzyme has a pH optimum of 7.8 and 8.2 in the $\gamma$-glutamyltransferase and $\gamma$-glutamylsynthetase assays, respectively, and a temperature optimum of $45^{\circ} \mathrm{C}$. Kinetic studies of GS revealed apparent $K_{\mathrm{m}}$ values of $5.9 \mathrm{mM}, 0.009 \mathrm{mM}$ and $8.6 \mathrm{mM}$ for glutamine, ADP and $\mathrm{NH}_{2} \mathrm{OH}$, respectively, in the $\gamma$-glutamyltransferase assay, and of $2.2 \mathrm{mM}, 0.12 \mathrm{mM}$ and $0.64 \mathrm{mM}$ for glutamate, ATP and $\mathrm{NH}_{2} \mathrm{OH}$, respectively, in the $\gamma$-glutamylsynthetase assay.
\end{abstract}

Keywords: Dictyostelium discoideum, glutamine synthetase, ammonia assimilation

\section{INTRODUCTION}

The cellular slime mould Dictyostelium discoideum is a freeliving soil micro-organism (Sussman \& Bradley, 1954). Initially cells grow as single-celled amoebae which phagocytose and feed on bacteria. Upon depletion of the bacterial food source or amino acid starvation, amoebae undergo an aggregation process in response to pulses of cAMP and enter a developmental sequence that results in the formation of a fruiting body. The fully differentiated fruiting body consists of two cell types: spore cells with the capacity to germinate into new vegetative amoebae, and non-viable stalk cells (Loomis, 1988).

Development in $D$. discoideum is a highly coordinated process, in which signalling between the cells seems to control both their differentiation into stalk and spore cells and the overall morphogenesis of the aggregate (Berks $e t$ al., 1991). A number of diffusible molecules of low molecular mass (morphogens) have been shown to play key roles in regulating development in $D$. discoideum. These include cAMP, differentiation-inducing factor (DIF), adenosine and ammonia (for a review see Williams, 1988). Ammonia has been shown to have a number of effects. It delays aggregation in aggregation-competent cells by lowering the overall level of intracellular cAMP

Abbreviations: BAL, 2,3-dimercapto-1-propanol; DIF, differentiationinducing factor; FITC, fluorescein isothiocyanate; GS, glutamine synthetase; MSX, methionine sulphoximine.
(Schindler \& Sussman, 1977, 1979; Thadani et al., 1977; Williams et al., 1984) thus inhibiting terminal differentiation. It has also been shown to inhibit DIF accumulation (Neave $e t$ al., 1983) and to act antagonistically to DIF by inducing genes specific to the prespore pathway and repressing expression of genes specific to the stalk pathway (Sternfeld \& David, 1979; Gross et al., 1983; Oyama et al., 1988). Furthermore ammonia has been shown to switch cells from the prestalk to the prespore pathway (Bradbury \& Gross, 1989).

On this basis it might be expected that the concentration of ammonia would be higher in prespore cells. However this is not the case; the level of ammonia is higher in prestalk cells (Feit reported in Cotter et al., 1992; Rutherford et al., 1982). A possible explanation for this apparent paradox is found in a model suggested by Insall et al. (1992). In this model once a group of cells begin to respond to a morphogen, then two events occur: (a) an increase in the sensitivity of the target cells to the morphogen and (b) removal of the morphogen. The combined effect of these two events is to prevent the morphogen rising to levels where it affects cells other than the initial group of target cells while allowing these cells to progress along the differentiation pathway.

In the case of ammonia, Cotter et al. (1992) extended this concept by proposing a source and sink model that predicts once differentiation has commenced ammonia production should occur in prestalk cells (i.e. the non- 
responsive group) and removal in the prespore cells (target group). These predictions are supported indirectly by a number of observations. Firstly there is extensive degradation of cellular macromolecules and therefore presumably release of ammonia in prestalk/prespore cells during differentiation, and secondly prespore cells accumulate large amounts of amino acids, especially glutamine and glutamate (Kelly et al., 1979; Klein et al., 1990).

It has been shown that both the NADH-dependent and the NADPH-dependent glutamate dehydrogenases exist in $D$. discoideum (Langridge et al., 1977; Pamula \& Wheldrake, 1990, 1991). During both vegetative growth and prestalk-stalk development it is likely that the $\mathrm{NADH}$-dependent glutamate dehydrogenase functions primarily to degrade glutamate from protein catabolism to 2-oxoglutarate and $\mathrm{NH}_{3}$. In prespore-spore development either the NADH- or NADPH-dependent glutamate dehydrogenase may function to remove $\mathrm{NH}_{3}$ via assimilation with 2-oxoglutarate to produce glutamate (Cotter et al., 1992). Furthermore, given the very high levels of free glutamine found in spores (Klein et al., 1990), ammonia may additionally be removed via the enzyme glutamine synthetase (L-glutamate ammonia ligase, ADP forming; EC 6.3.1.2) (GS) which catalyses the biosynthesis of glutamine from ammonia:

$$
\mathrm{NH}_{3}+\text { glutamate }+\mathrm{ATP} \rightarrow \text { glutamine }+\mathrm{ADP}+\mathrm{P}_{\mathrm{i}}
$$

It is clear that the GS would be expected to play an important role in the removal of ammonia and the generation of an ammonia gradient. In this paper we demonstrate the presence of this enzyme in $D$. discoideum, describe some of its properties and examine its developmental regulation and cell type distribution.

\section{METHODS}

Reagents. L-Glutamine, L-glutamate, $y$-glutamyl monohydroxamate, L-methionine sulphoximine (MSX), Pronase and 2,3-dimercapto-1-propanol (BAL) were from Sigma. ATP, $\mathrm{ADP}$, and anti-mouse Ig-fluorescein were from BoehringerMannheim. Percoll was from Pharmacia and hydroxylamine from $\mathrm{BDH}$. Mouse anti- $D$. discoideum spore serum was a kind gift from Professor K. L. Williams (Maquarie University, Sydney, Australia). Media components were purchased from Oxoid.

Culture conditions. $D$. discoideum (strain V12) were grown in liquid co-culture in $\mathrm{KK} 2$ buffer at $22^{\circ} \mathrm{C}$, using Enterobacter aerogenes as a food source, to $3-5 \times 10^{6}$ cells ml ${ }^{-1}$ (Pamula \& Wheldrake, 1988). Cells washed three times in ice-cold KK2 buffer to free them of bacteria were used for the preparation of growth-phase (vegetative) cells. $D$. discoideum strain AX3 was grown in HL5 medium as described by Sussman (1987). To obtain cells at various stages of morphogenesis, washed vegetative amoebae were resuspended in KK2 to a density of $5.5 \times 10^{8}$ cells $\mathrm{ml}^{-1}$ and allowed to develop for selected times on cellulose nitrate membrane filters ( $4.5 \mathrm{~cm}$ diameter, Whatman), resting on supporting filter pads saturated with $\mathrm{KK} 2$ at $22^{\circ} \mathrm{C}$. Both vegetative and differentiating-stage cells were harvested by centrugation at $200 \mathrm{~g}\left(5 \mathrm{~min}, 4^{\circ} \mathrm{C}\right)$, washed three times in $\mathrm{KK} 2$, snap-frozen in liquid nitrogen and stored at $-20^{\circ} \mathrm{C}$ until required.
Isolation of prestalk and prespore cells. Separation of prestalk and prespore cells was based on a modified method of Tsang \& Bradbury (1981). Briefly, vegetative cells prepared as described above were collected and allowed to form slugs at $22^{\circ} \mathrm{C}$ on $1.5 \%$ (w/v) KK2 agar. Slugs were harvested in cold KK2 and centrifuged at $200 \mathrm{~g}\left(5 \mathrm{~min}, 4^{\circ} \mathrm{C}\right)$ and the resulting cell pellet was resuspended in 10 vols dissociation buffer $(0.1 \%$ Pronase, $25 \mathrm{mM} \mathrm{BAL}$ in $50 \mathrm{mM}$ Tris/HCl, $\mathrm{pH} 7 \cdot 0$ ). Slugs were then dissociated after $30 \mathrm{~min}$ at room temperature by passing them four times through a 25 gauge needle. Dissociated slug cells were then filtered through stainless steel mesh $(25 \mu \mathrm{m}$ pore size $)$ layered onto a preformed $(30000 \mathrm{~g}, 10 \mathrm{~min})$ gradient of $70 \%$ (v/v) Percoll (containing $20 \mathrm{mM}$ potassium phosphate, $2 \mathrm{mM}$ EDTA, $0.65 \% \mathrm{NaCl}, \mathrm{pH} 6.9)$ and centrifuged at $400 \mathrm{~g}(10 \mathrm{~min}$, $4{ }^{\circ} \mathrm{C}$ ). Resulting prestalk (light fraction) and prespore (heavy fraction) cells were carefully removed from the gradient and resuspended in 5 vols KK2. Prestalk cells and prespore cells were collected by centrifugation at $2500 \mathrm{~g}\left(10 \mathrm{~min}, 4^{\circ} \mathrm{C}\right)$ and $400 \mathrm{~g}\left(5 \mathrm{~min}, 4^{\circ} \mathrm{C}\right)$ respectively. To confirm that the exposure of slugs to BAL/Pronase did not effect GS activity, slugs were incubated in the presence and absence of BAL/Pronase at room temperature for $30 \mathrm{~min}$ and GS activity subsequently determined. The effectiveness of the separation of the two cell types was assessed by incubating cells with mouse anti- $D$. discoideum spore serum, followed by FITC-conjugated sheep anti-mouse IgG by the method of Durston et al. (1984). The ratio of fluorescent to non-fluorescent cells was determined by scoring on a Zeiss fluorescence microscope.

Preparation of cell extracts. All the following operations were performed at or below $4{ }^{\circ} \mathrm{C}$. Cell pellets were resuspended in 10 vols $50 \mathrm{mM}$ HEPES ( $\mathrm{pH} 7 \cdot 8$ ) and disrupted by sonication as previously described (Dunbar \& Wheldrake, 1994). The homogenate was centrifuged at $100000 \mathrm{~g}$ (20 $\mathrm{min}$ ) to remove cellular debris. The resulting supernatant was desalted by passage through Sephadex G-25 M (PD-10, Pharmacia), filtered through a $0.22 \mu \mathrm{m}$ filter (Millex-GV, Millipore) and retained for all experiments. Protein concentration of the extract was determined by the method of Bradford (1976) using BSA (Fraction V) as the standard.

Enzyme assay. GS activity was measured spectrophotometrically using the $\gamma$-glutamyltransferase and $\gamma$-glutamylsynthetase assays described by Meister (1985). $\gamma$-Glutamyltransferase activity was followed by measuring the formation of $\gamma$-glutamyl monohydroxamate in the reaction mixture which contained in a final volume of $1 \mathrm{ml}: 50 \mathrm{mM}$ HEPES ( $\mathrm{pH} 7 \cdot 8$ ), $40 \mathrm{mM}$ glutamine, $30 \mathrm{mM}$ sodium arsenate, $1 \mathrm{mM} \mathrm{MnCl}_{2}$ or $20 \mathrm{mM} \mathrm{MgSO}_{4}, 30 \mathrm{mM} \mathrm{HCl} /$ hydroxylamine neutralized just before use, $0.1 \mathrm{mM}$ ADP and an appropriate amount of enzyme. The reaction was initiated by the addition of either ADP or enzyme and incubated at $30^{\circ} \mathrm{C}$ for $30 \mathrm{~min}$. $\gamma$-Glutamyltransferase activity in the absence of glutamine was used as the control. $\gamma$-Glutamylsynthetase activity was followed by measuring the formation of $\gamma$-glutamyl monohydroxamate in the reaction mixture which contained in a final volume of $1 \mathrm{ml}$ : $50 \mathrm{mM}$ HEPES ( $\mathrm{pH} \mathrm{8 \cdot 2),} 100 \mathrm{mM}$ glutamate, $20 \mathrm{mM} \mathrm{MgSO}_{4}$, $30 \mathrm{mM} \mathrm{HCl} /$ hydroxylamine neutralized just before use, $10 \mathrm{mM} \mathrm{ATP}$ and an appropriate amount of enzyme. The reaction was initiated by the addition of either ATP or enzyme and incubated at $30^{\circ} \mathrm{C}$ for $30 \mathrm{~min}$. $\gamma$-Glutamyltransferase activity in the absence of glutamate was used as the control. $\gamma$ Glutamyl monohydroxamate was colorimetrically determined by addition of $1 \mathrm{ml}$ ferric chloride reagent $\left(370 \mathrm{mM} \mathrm{FeCl}_{3}\right.$, $200 \mathrm{mM} \mathrm{TCA}$ and $670 \mathrm{mM} \mathrm{HCl})$. Samples were centrifuged at $12000 \mathrm{~g}(3 \mathrm{~min})$ to remove precipitated material. The $A_{540}$ of the supernatant was measured after $20 \mathrm{~min}$ and the amount of $y$ glutamyl monohydroxamate calculated by reference to a stan- 
dard curve constructed with commercial $\gamma$-glutamyl monohydroxamate. The specific activity of GS is expressed in nmol $\gamma$ glutamylmonohydroxamate $\mathrm{min}^{-1}$ (mg protein) ${ }^{-1}$.

\section{RESULTS}

\section{GS activity in $D$. discoideum crude extracts}

GS activity could be detected in crude extracts from $D$. discoideum using either the $\gamma$-glutamyltransferase or the $\gamma$ glutamylsynthetase assay. GS activity catalysing the $\mathrm{Mg}^{2+}$-dependent $\gamma$-glutamyltransferase reaction showed an absolute requirement for $\mathrm{Mg}^{2+}$ and ADP. Less than $7 \% \gamma$-glutamylmonohydroxamate was produced in the absence of either $\mathrm{NH}_{2} \mathrm{OH}$, arsenate or glutamine. Similarly in the absence of either $\mathrm{Mg}^{2+}$ or ATP no GS activity was detected in the $\gamma$-glutamylsynthetase reaction and less than $4 \% \gamma$-glutamylmonohydroxamate was produced in the absence of either $\mathrm{NH}_{2} \mathrm{OH}$ or glutamate. $\gamma$-Glutamyltransferase activity was approximately fivefold higher when $\mathrm{Mg}^{2+}$ was replaced by $\mathrm{Mn}^{2+}$ as the divalent cation. All of the components of the $\mathrm{Mn}^{2+}$-dependent $\gamma$-glutamyltransferase reaction were required for the production of $\gamma$ glutamylhydroxamate except that activity in the absence of ADP was approximately $70 \%$ of that of the complete assay mixture. Thus unlike the $\mathrm{Mg}^{2+}$-dependent activity the reaction catalysed by $\mathrm{Mn}^{2+}$ did not have an absolute requirement for ADP but was stimulated by approximately $30 \%$ on addition of this nucleotide. In the $\gamma$ glutamylsynthetase reaction $\mathrm{Mn}^{2+}$ did not support GS activity.

To confirm the GS activity was not of bacterial origin the enzyme assays were performed using $D$. discoideum $\mathrm{AX} 3$ cells grown in axenic culture and similar results were obtained (data not shown).

\section{Effect of MSX}

Apart from GS, $\gamma$-glutamylhydroxamate formation can also be catalysed by other enzymes such as glutaminases, amidotransferases (Meister, 1980) and $\gamma$-glutamyltranspeptidases (Orlowski \& Meister, 1970). To confirm that the formation of $\gamma$-glutamylhydroxamate is a function of GS and not some other enzyme activity $\mathrm{Mn}^{2+}$ dependent $\gamma$-glutamyltransferase and $\gamma$-glutamylsynthetase activities were measured in the presence of the specific GS inhibitor MSX (Genetet et al., 1984). In the presence of MSX both activities decreased with increasing MSX up to $5.0 \mathrm{mM}$ (Fig. 1). $50 \%$ inhibition was apparent at approximately $0.1 \mathrm{mM}$. A similar result was obtained for the $\mathrm{Mg}^{2+}$-dependent $\gamma$-glutamyltransferase reaction (data not shown).

\section{Kinetic properties of GS}

The apparent $\mathrm{pH}$ optimum measured by both the $\mathrm{Mn}^{2+}\left(\mathrm{Mg}^{2+}\right)$-dependent $\gamma$-glutamyltransferase assay and the $\gamma$-glutamylsynthetase assay was 7.8 and 8.2 respectively. The temperature optimum for both assays was $45^{\circ} \mathrm{C}$. At temperatures above $45^{\circ} \mathrm{C}$, thermal inactivation caused a rapid decrease in GS activity (data not shown).

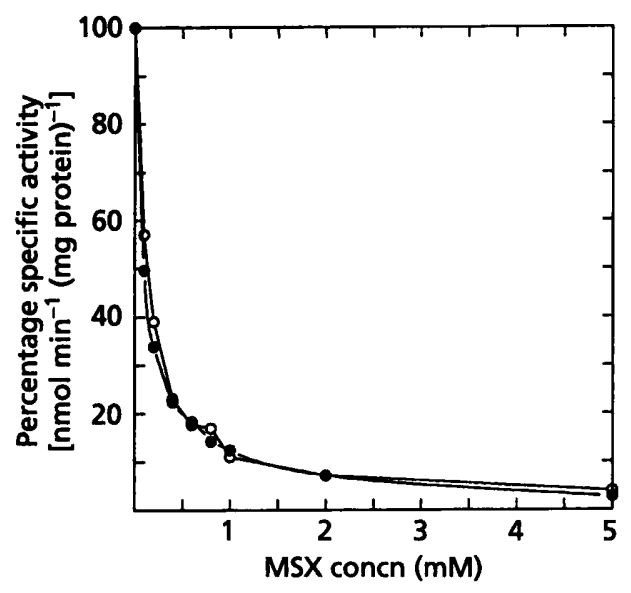

Fig. 1. Effect of MSX on GS activity. Increasing concentrations of MSX were included in the $\mathrm{Mn}^{2+}$-dependent $\gamma$ glutamyltransferase $(O)$ and $\gamma$-glutamylsynthetase $(O)$ reaction mix containing enzyme and incubated at $30^{\circ} \mathrm{C}$ for $5 \mathrm{~min}$ before the reaction was initiated with ADP. Each point on the graph represents the mean of triplicate determinations. For $\mathrm{Mn}^{2+}$-dependent $\gamma$-glutamyltransferase activity, $100 \%=$ $79.5 \mathrm{nmol} \mathrm{min}^{-1}$ (mg protein) $)^{-1}$; for $\gamma$-glutamylsynthetase activity, $100 \%=11.7 \mathrm{nmol}^{\mathrm{min}^{-1}}$ (mg protein) ${ }^{-1}$. This experiment was repeated twice with similar results.

All subsequent assays were done under optimum conditions except that the temperature was $30^{\circ} \mathrm{C}$, which is close to the growth temperature for $D$. discoideum. For the determination of Michaelis-Menten constants for the $\gamma$ glutamyltransferase and $\gamma$-glutamylsynthetase activities, one substrate concentration was varied while the others were kept near saturation. In the $\mathrm{Mg}^{2+}$-dependent $\gamma$ glutamyltransferase assay the $K_{\mathrm{m}}$ values for glutamine, $\mathrm{ADP}$, and $\mathrm{NH}_{2} \mathrm{OH}$ were $5.9 \mathrm{mM}, 0.009 \mathrm{mM}$, and $8.6 \mathrm{mM}$ respectively. Identical $K_{\mathrm{m}}$ values were obtained for the $\mathrm{Mn}^{2+}$-dependent $\gamma$-glutamyltransferase assay. For the $\gamma$ glutamylsynthetase assay the $K_{\mathrm{m}}$ values for glutamate, ATP and $\mathrm{NH}_{2} \mathrm{OH}$ were $2.2 \mathrm{mM}, 0.12 \mathrm{mM}$ and $0.64 \mathrm{mM}$, respectively.

\section{Developmental time course}

In order to determine the role GS may play during development in the generation of an ammonia gradient, GS activity was determined at $4 \mathrm{~h}$ intervals following the onset of differentiation (Fig. 2). GS activity was found to rise very sharply at the late pseudoplasmodium stage $(16 \mathrm{~h})$ and peak at the Mexican hat stage $(20 \mathrm{~h})$ before declining with the formation of the fruiting body. Sonication may not release all of the enzyme at various stages of differentiation, in particular the last stages of culmination and fruiting body maturation. Therefore it was important to confirm that the changes in GS activity were not a result of differential release of the enzyme following sonication. To do this, cell extracts were prepared from all stages of development either by glassbead grinding (Sigma type 1, 75-105 $\mu \mathrm{m}$ ) or by Dounce homogenization. All three extraction techniques gave very similar results. 


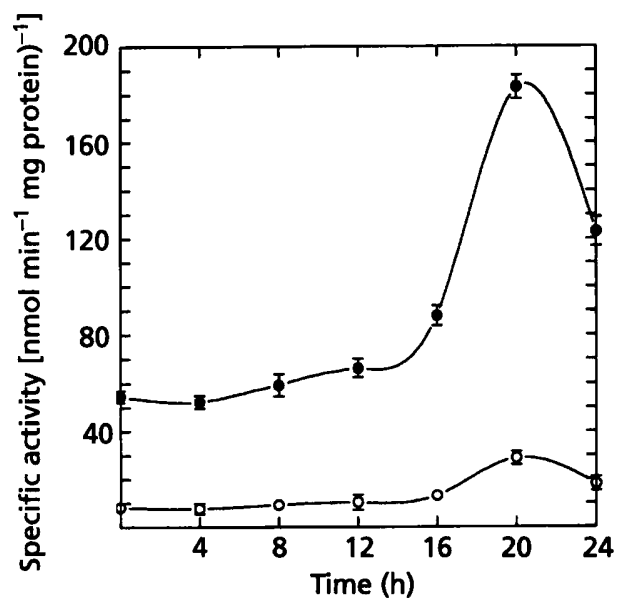

Fig. 2. Developmental time course of GS activity. Crude extracts were prepared from cells harvested at $0,4,8,12,16,20$, and $24 \mathrm{~h}$ after the onset of differentiation as described in Methods. At each time point GS activity was determined using both the $\mathrm{Mn}^{2+}$-dependent $\gamma$-glutamyltransferase (O) and $\gamma$ glutamylsynthetase $(O)$ assays. Each point on the graph represents the mean of triplicate determinations \pm SEM. This experiment was repeated three times with similar results.

\section{Table 1. Cell type distribution of GS activity}

Prestalk and prespore cells were separated as described in Methods and GS activity was determined using both the $\mathrm{Mn}^{2+}$ dependent $\gamma$-glutamyltransferase and $\gamma$-glutamylsynthetase assays. Each experiment contained three separate preparations of each cell type and for each cell type assays were performed in triplicate. All values presented are the means of triplicate determinations of each cell type \pm sEM

\begin{tabular}{|c|c|c|c|}
\hline \multirow[t]{2}{*}{$\begin{array}{l}\text { Expt } \\
\text { no. }\end{array}$} & \multirow[t]{2}{*}{ Cell type } & \multicolumn{2}{|c|}{$\begin{array}{c}\text { Specific activity } \\
{\left[\mathrm{nmol} \mathrm{min}^{-1}(\mathrm{mg} \text { protein })^{-1}\right]}\end{array}$} \\
\hline & & $\begin{array}{l}\gamma \text {-Glutamyl- } \\
\text { transferase }\end{array}$ & $\begin{array}{c}\gamma \text {-Glutamyl- } \\
\text { synthetase }\end{array}$ \\
\hline 1 & $\begin{array}{l}\text { Prestalk } \\
\text { Prespore }\end{array}$ & $\begin{array}{l}22 \cdot 13 \pm 0 \cdot 22 \\
91 \cdot 62 \pm 1 \cdot 13\end{array}$ & $\begin{array}{l}2 \cdot 16 \pm 0 \cdot 34 \\
8 \cdot 23 \pm 0 \cdot 71\end{array}$ \\
\hline 2 & $\begin{array}{l}\text { Prestalk } \\
\text { Prespore }\end{array}$ & $\begin{array}{l}22 \cdot 26 \pm 1 \cdot 41 \\
93 \cdot 82 \pm 4 \cdot 21\end{array}$ & $\begin{array}{l}2 \cdot 10 \pm 0 \cdot 49 \\
7 \cdot 98 \pm 0 \cdot 85\end{array}$ \\
\hline 3 & $\begin{array}{l}\text { Prestalk } \\
\text { Prespore }\end{array}$ & $\begin{array}{l}23 \cdot 12 \pm 0.77 \\
89.53 \pm 0.22\end{array}$ & $\begin{array}{l}2 \cdot 71 \pm 0.14 \\
8.39 \pm 0.22\end{array}$ \\
\hline
\end{tabular}

\section{Cell type distribution}

The source and sink model (Cotter et al., 1992) predicts that ammonia is removed from prespore cells via the biosynthesis of glutamine and subsequently there should be differential localization of GS in prespore and prestalk cells. In order to test this hypothesis, prestalk and prespore cells were separated and GS activity was determined in the two cell types (Table 1). In three separate experiments GS activity was found to be approximately fourfold higher in prespore cells than in prestalk cells. Immunofluorescent staining of cells with an antibody highly specific to prespore cells conjugated to FITC-labelled sheep antimouse IgG was used to determine the purity of separation of the two cell types. The range of contamination of the prestalk fraction by prespore cells was routinely 5-10\% (data not shown). The GS activity of the prestalk cells shown in Table 1 has been corrected for the contamination. Recently Bonner (1993) has shown that proteolytic enzymes such as papain may result in ammonia production in slug tissue over short time periods. The relevant control experiment (see Methods) indicates that the exposure of slugs to BAL/Pronase does not affect GS activity (data not shown) and that the observed values of GS activity are a true measure of native GS levels unaffected by experimental manipulation.

\section{DISCUSSION}

During the morphogenesis of $D$. discoideum, the level of ammonia rises as protein-rich unicellular amoebae are induced to turn over their proteins during the formation of multicellular fruiting bodies. In many organisms, particularly mammals, the level of free ammonia is controlled by GS (Mathews \& Van Holde, 1990). Given the high levels of glutamine present in dormant spores of the Dictyostelium (Klein et al., 1990) one possible role for GS may be to control the levels of free ammonia during differentiation.

This paper reports the presence of GS in $D$. discoideum. The enzyme could use either $\mathrm{Mg}^{2+}$ or $\mathrm{Mn}^{2+}$ as the divalent cation in the $\gamma$-glutamyltransferase assay, although $\mathrm{Mn}^{2+}$ gave an approximately fivefold higher activity than $\mathrm{Mg}^{2+}$. The $\mathrm{Mn}^{2+}$-dependent $\gamma$-glutamyltransferase activity was approximately ninefold higher than the $\mathrm{Mg}^{2+}$-dependent $\gamma$-glutamylsynthetase activity. Similar findings have been reported for GS from a variety of organisms, including the basidiomycete fungi Pleurotus ostreatus (Mikes et al., 1994) and Stropharia semiglobata (Schwartz et al., 1991).

A significant amount of $\gamma$-glutamylmonohydroxamate was produced in the $\mathrm{Mn}^{2+}$-dependent $\gamma$-glutamyltransferase reaction in the absence of ADP. A similar effect has previously been observed in Anabaena cylindrica (Sawhney \& Nicholas, 1978). The requirement for both $\mathrm{Mn}^{2+}$ and arsenate and inhibition by MSX indicated that this reaction was catalysed by GS as opposed to other possible contaminants such as glutaminases, amidotransferases (Meister, 1980) and $\gamma$-glutamyltranspeptidases (Orlowski \& Meister, 1970). In the $\mathrm{Mg}^{2+}$-dependent $\gamma$ glutamyltransferase reaction no $\gamma$-glutamylmonohydroxamate was produced in the absence of ADP. Thus the ADP-independent activity does not appear to be due to ADP bound to the enzyme. It is possible that $\mathrm{Mg}^{2+}$ and $\mathrm{Mn}^{2+}$ stabilize different conformational states of the enzyme and the one induced by $\mathrm{Mn}^{2+}$ is partially active in the absence of added ADP.

The relatively high optimum reaction temperature for both the $\gamma$-glutamyltransferase and $\gamma$-glutamylsynthetase activities is in agreement with the values from other sources (Canovas et al., 1984; Ertan, 1992; Shatters et al., 
1993). The reported $K_{\mathrm{m}}$ values are apparent values since the enzyme has not yet been purified. The $K_{\mathrm{m}}$ values do however confirm that the concentrations of reactants used in both assays were in excess and not rate-limiting. The $K_{\mathrm{m}}$ values for ATP and glutamate in the $\gamma$-glutamylsynthetase assay are similar to the concentrations of ATP $(0.7 \mathrm{mM})$ (Wright \& Kelly, 1981) and glutamate $(2.3 \mathrm{mM})$ (Kelly et al., 1979) in differentiating D. discoideum cells. It is likely then that GS plays a physiological role in the conversion of ammonia to glutamine.

GS from $D$. discoideum is developmentally regulated. Late differentiation-stage cells (Mexican hat) have an approximate threefold increase in activity compared to vegetative stage cells. The rise in GS activity and the concomitant rise in glutamine (Klein et al., 1990) may serve a number of functions : firstly to allow the generation of an ammonia gradient; secondly, to avoid nitrogen loss (in the form of ammonia) since this is a scarce resource in soil environments; and thirdly to accumulate reserves of readily available nitrogen required for spore germination (Klein et al., 1990).

GS activity has been shown to be differentially localized in prespore cells, suggesting that GS is a late prespore induced enzyme that is also present in vegetative cells. A number of questions arise from this. Firstly, is the vegetative enzyme the same as the differentiating enzyme? In plants, for example, there are cytosolic (GS1) and plastidic (GS2) isoenzymes of GS (McNally \& Hirel, 1983), and in bacteria three types of GS, termed GSI, GSII, and GSIII have been described (Woods \& Reid, 1993). It is therefore possible that separate vegetative and differentiating GS isoenzymes may exist. Secondly, what level of control operates on the enzyme throughout differentiation? These questions are currently under investigation.

\section{REFERENCES}

Berks, M., Traynor, D., Carrin, I., Insall, R. H. \& Kay, R. R. (1991). Diffusible signal molecules controlling cell differentiation and patterning in Dictyostelium. Development 1, 131-139.

Bonner, J. T. (1993). Proteolysis and orientation in Dictyostelium slugs. J Gen Microbiol 139, 2319-2322.

Bradbury, J. M. \& Gross, J. D. (1989). The effect of ammonia on cell-type-specific enzyme accumulation in Dictyostelium discoideum. Cell Differ Dev 27, 121-128.

Bradford, M. M. (1976). A rapid and sensitive method for the quantitation of microgram quantities of protein utilizing the principle of protein-dye binding. Anal Biochem 72, 248-254.

Canovas, F., Valpuesta, V. \& De Castro, I. N. (1984). Characterisation of tomato leaf glutamine synthetase. Plant Sci Lett 37, 79-85.

Cotter, D. A., Sands, T. W., Virdy, K. J., North, M. J., Klein, G. \& Satre, M. (1992). Patterning of development in Dictyostelium discoideum - factors regulating growth, differentiation, spore dormancy, and germination. Biochem Cell Biol 70, 892-919.

Dunbar, A. J. \& Wheldrake, J. F. (1994). A calcium and calmodulindependent protein kinase present in differentiating Dictyostelium discoideum. FEMS Microbiol Lett 115, 113-118.
Durston, A. J., Weijer, C. J., Jongkind, J. F., Verkerk, A., Timmermans, A. \& Te Kulve, W. (1984). A flow fluorimetric analysis of the cell cycle during growth and differentiation in Dictyostelium discoideum. Roux's Arch Dev Biol 194, 18-24.

Ertan, H. (1992). Some properties of glutamate dehydrogenase, glutamine synthetase and glutamate synthase from Corynebacterium callunae. Arch Microbiol 158, 35-41.

Genetet, I., Martin, F. \& Stewart, G. R. (1984). Ammonium assimilation in the $\mathrm{N}$-starved ectomycorrhizal fungus Cenococcum graniforme. Plant Pbysiol 76, 395-399.

Gross, J. D., Bradbury, J., Kay, R. R. \& Peacey, M. J. (1983). Intracellular $\mathrm{pH}$ and the control of cell differentiation in Dictyostelium discoideum. Nature 303, 244-245.

Insall, R., Nayler, O. \& Kay, R. R. (1992). DIF-1 induces its own breakdown in Dictyostelium. EMBO J 11, 2849-2854.

Kelly, P. J., Kelleher, J. K. \& Wright, B. E. (1979). The tricarboxylic acid cycle in Dictyostelium discoideum. Biocbem J 184, 581-588.

Klein, G., Cotter, D. A., Martin, J. B. \& Satre, M. (1990). A natural abundance ${ }^{13} \mathrm{C}-\mathrm{NMR}$ study of Dictyostelium discoideum metabolism. Eur J Biochem 193, 135-142.

Langridge, W. H., Komuniecki, P. \& DeToma, F. J. (1977). Isolation and regulatory properties of two glutamate dehydrogenases from the cellular slime mould Dictyostelium discoideum. Arch Biochem Biopbys 178, 581-587.

Loomis, W. F. (1988). Signals that regulate differentiation in Dictyostelium. ISI Atlas Science: Immunology 1, 25-30.

Mathews, C. K. \& van Holde, K. E. (1990). Metabolism of nitrogenous compounds: principles of biosyntheseis, utilization, turnover, and excretion. In Biochemistry, pp. 670-703. New York: Benjamin/Cummings Publishing Co.

McNally, S. \& Hirel, B. (1983). Glutamine synthetase isoforms in higher plants. Pbysiol Veg 21, 761-774.

Meister, A. (1980). Catalytic mechanism of glutamine synthetase; overview of glutamine metabolism. In Glutamine: Metabolism, Enzymology, and Regulation, pp. 1-40. Edited by J. Mora \& R. Palacios. New York: Academic Press.

Meister, A. (1985). Glutamine synthetase from mammalian tissues. Methods Enqymol 113, 185-199.

Mikes, V., Zofall, M., Chytil, M., Fulnecek, J. \& Schanel, L. (1994). Ammonia-assimilating enzymes in the basidiomycete fungus Pleurotus ostreatus. Microbiology 140, 977-982.

Neave, N., Sobolewski, A. \& Weeks, G. (1983). The effect of ammonia on stalk cell formation in submerged monolayers of Dictyostelium discoideum. Cell Differ 13, 301-307.

Orlowski, M. \& Meister, A. (1970). $\gamma$-Glutamyl transpeptidase (hog kidney). Methods Enzymol 17A, 883-889.

Oyama, M., Kubohara, Y., Oohata, A. A. \& Okamoto, K. (1988). Role of cyclic AMP and ammonia in induction and maintenance of post-aggegative differentiation in a suspension culture of Dictyostelium discoideum. Differentiation 38, 11-16.

Pamula, F. \& Wheldrake, J. F. (1988). Properties and developmental regulation of the protein phosphatases in Dictyostelium discoideum. Biochem Int 17, 535-543.

Pamula, F. \& Wheldrake, J. F. (1990). Activation of the NADHdependent glutamate dehydrogenase during morphogenesis of Dictyostelium discoideum. Biochem Int 20, 623-631.

Pamula, F. \& Wheldrake, J. F. (1991). Purification and properties of the NADP-dependent glutamate dehydrogenase from Dictyostelium discoideum. Mol Cell Biochem 105, 85-92. 
Rutherford, C. L., Taylor, R. D., Merkle, R. K. \& Frame, L. T. (1982). Cellular pattern formation: Dictyostelium discoideum as a system for a biochemical approach. Trends Biochem Sci 107, 108-111.

Sawhney, S. K. \& Nicholas, D. J. D. (1978). Some properties of glutamine synthetase from Anabaena cylindrica. Planta 139, 289-299.

Schindler, J. \& Sussman, M. (1977). Effect of $\mathrm{NH}_{3}$ on c-AMP associated activities and extracellular c-AMP production in Dictyostelium discoideum. Biochem Biophys Res Commun 79, 611-617.

Schindler, J. \& Sussman, M. (1979). Inhibition by ammonia of intracellular cAMP accumulation in Dictyostelium discoideum: its significance for the regulation of morphogenesis. Dev Genet 1, 13-20.

Schwartz, T., Kusnan, M. B. \& Fock, H. P. (1991). The involvement of glutamate dehydrogenase and glutamine synthetase/glutamate synthase in ammonia assimilation by the basidiomycete fungus Stropharia semiglobata. J Gen Microbiol 137, 2253-2258.

Shatters, R. G., Liu, Y. \& Kahn, M. L. (1993). Isolation and characterisation of a novel glutamine synthetase from Rhizobium meliloti. J Biol Chem 268, 469-475.

Sternfeld, J. \& David, C. N. (1979). Ammonia plus another factor are necessary for differentiation in submerged clumps of Dictyostelium. J Cell Sci 38, 181-191.

Sussman, M. (1987). Cultivation and synchronous morphogenesis of Dictyostelium under controlled experimental conditions. Methods Cell Biol 28, 9-29.
Sussman, M. \& Bradley, S. G. (1954). A protein growth factor of bacterial origin required by the cellular slime molds. Arch Biochem Biopbys 51, 428-435.

Thadani, V., Pan, P. \& Bonner, J. T. (1977). Complementary effects of ammonia and cAMP on aggregation territory size in the cellular slime mould Dictyostelium mucuroides. Exp Cell Res 108, 75-78.

Tsang, A. \& Bradbury, J. M. (1981). Separation and properties of prestalk and prespore cells of Dictyostelium discoideum. Exp Cell Res 132, 433-441.

Williams, J. G. (1988). The role of diffusible molecules in regulating the cellular differentiation of Dictyostelium discoideum. Development 103, 1-16.

Williams, G. B., Elder, E. M. \& Sussman, M. (1984). Modulation of the cAMP relay in Dictyostelium discoideum by ammonia and other metabolites: possible morphogenetic consequences. Dev Biol 105, 377-388.

Woods, D. R. \& Reid, S. J. (1993). Recent developments on the regulation and structure of glutamine synthetase enzymes from selected bacterial groups. FEMS Microbiol Lett 11, 273-284.

Wright, B. E. \& Kelly, P. J. (1981). Kinetic models of metabolism in intact cells, tissues, and organisms. Curr Top Cell Reg 19, 103-158.

Received 19 September 1994; revised 17 December 1994; accepted 13 January 1995. 